\title{
Characteristics of Melodies in Bellini's Art Songs
}

\author{
Qinwen Yang \\ School of Art and Design \\ Yunnan University \\ Kunming, China
}

\begin{abstract}
Bellini's art songs are beautiful, lyric, romantic and cantabile. They are regarded as the classic teaching materials for vocal music. While adhering to the writing tradition of Italy bel canto singing, Bellini's artistic songs played a great role in promoting the voice development and singing skills of singers. This article, from the angle of singing melody of Bellini's art songs, has made detailed analysis on characteristics of the special singing melodies with the combination of concrete music scores. It is very useful for the improvement of singing level, artistic culture and teaching level of vocal music teachers.
\end{abstract}

Keywords-Bellini; art songs; singing melody; characteristics

\section{INTRODUCTION}

Vincenzo Bellini (1801 1835) was a famous romantic opera composer in Italy in the 19th century. He was born in a highly musical family in the Catania of Sicily on November 3,1801 . His grandfather had studied at the conservatory in Naples and had been an organist and teacher in Catania, as had his father. They were both composers and music teachers. So Bellini was inspired by music from his childhood. At the age of three, he began to learn music. At the age of five, he was able to play piano skillfully. At the age of six, he wrote the first music works. And his hearing and memory in music are very good, showing extraordinary musical talent. Then he studied composing with his grandfather and wrote a lot of religious music. In 1819, Bellini was lucky enough to have an aristocratic patron and begin his formal music study in Conservatorio di San Sebastiano in Naples at the age of 18 . He studied composition and conducting from current famous composer Zingarelli. At this time, he carefully studied and researched classic works of Haydn, Mozart and Napoli Music School. But in his whole life he was prone to all kinds of sickness. Bellini died of dysentery at the age of 34 in Peteaux, France on September 23, 1835.

Bellini was famous for his composition of opera. He wrote 11 operas. The most famous are I puritani, Norma and La Sonnanbula. However, Bellini's music composition was widely involved in. He also wrote more than 20 pieces of art songs. The most popular are Vaga luna, che inargenti and Malinconia, Ninfa Gentile. His famous music works also include Marcia (March in 1813) and six pieces of symphony and some religious music, mass and Oboe concertos.

\section{THE CHARACTERISTICS OF MELODIES IN BELLINI'S ART SONGS}

The melody of Bellini's art songs has been well adhering to the aesthetic melody style of Italy's bel canto tradition. It is famous for its beauty, broadness, coherence and longflowing lyricism. It's very romantic and cantabile. His music has influenced the composition of Verdi, Chopin and Wagner. Stravinsky has compared Bellini's music to Beethoven's music, known as two B. He thought, "when Beethoven didn't master the melody, he was composing. Bellini was writing tirelessly the natural and beautiful melodies, though he didn't seem to realize it" ${ }^{1}$. Verdi also liked and cherished Bellini's music works. In his letter, he wrote, "of course, Bellini's works are lacking in orchestral law and harmony, but his personal feelings of sadness are very rich. Even in the most unpopular works, there are waterflowing melodies. His works were such clear and sweet without parallel in history. Indeed, there are shortcomings in orchestra, but before him there was no one who can wrote such a beautiful and inspiring melody" 4 . In fact, the most charismatic and unique parts are the melodic characteristics in Bellini's art songs.

\section{A. Vaulted Musical Line (Lyrical Vocal Bellini Melody)}

Vaulted music line, also known as "lyrical vocal Bellini melody", refers to the unique music melody in Bellini's works. Under the accompany of broken chords of low parts, vocal melody begins by broad long tones, gradually forms the climax, and then returns back to broad long tones, forming a vaulted line. This unique melody is good at expressing gentle melancholy and sad feelings, which is touching and with a romantic taste. This melody is often compared with the sentimental melody of Chopin ${ }^{3}$. Bellini's art songs very frequently used this vaulted musical line as the singing melody, and the vaulted musical lines in his art songs are beautiful and soothing, with ups and downs. The melody is elegant and refined, long-flowing and broad, gentle and lyric, natural and gorgeous. For example, the works include L'abbandono, $\mathrm{O}$ crudel che il mio pianto non vedi and L'allegro marinaro as shown in "Fig. 1", "Fig. 2" and "Fig. 3".

\footnotetext{
${ }^{1}$ Music Bible, Lin Yicong. Huaxia Publishing House, 1999.

${ }^{2}$ Selection of Bellini's Art Songs, translated by Jia Tao. Central Conservatory of Music Press, 2008.

${ }^{3} \mathrm{http}: / / \mathrm{www}$. shanghaiopera.com.cn/Gjtd_gjmj_show.asp? Info_id=212
} 


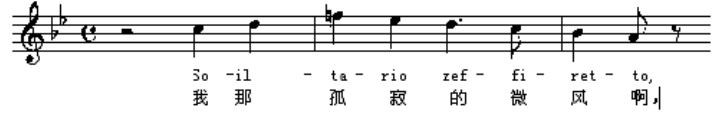

Fig. 1. Extracted from L'abbandono.

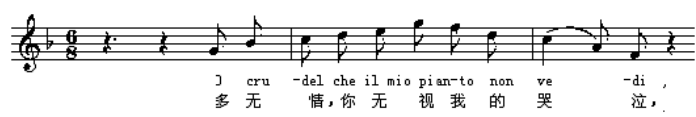

Fig. 2. Extracted from $\mathrm{O}$ crudel che il mio pianto non vedi.

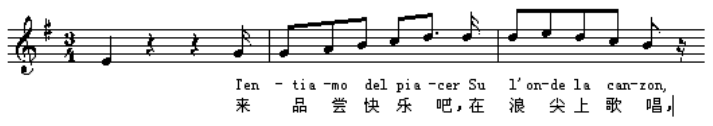

Fig. 3. Extracted from L'allegro marinaro.

Secondly, the melody of Bellini's art songs is often connected by several vaulted melodic lines, showing a form of rolling wave, like a long-flowing stream. The waved melodic line is very uniform and balanced: a descending melody follows an ascending melody; then follows another ascending melody continuously. In addition, the length and height of the ascending melodic lines and descending melodic lines are quite similar. The melody is carried out in a graded and smooth way, forming a balance and regular state. This gives a sense of ease, regularity, balance and flow. With classical style, it is very elegant and romantic. The waved melody appears ups and downs, long-stretched, broad and grand. For example, the works include L'abbandono, Vaga luna, che inargenti and Malinconia, Ninfa gentile as in "Fig. 4", "Fig. 5" and "Fig. 6".

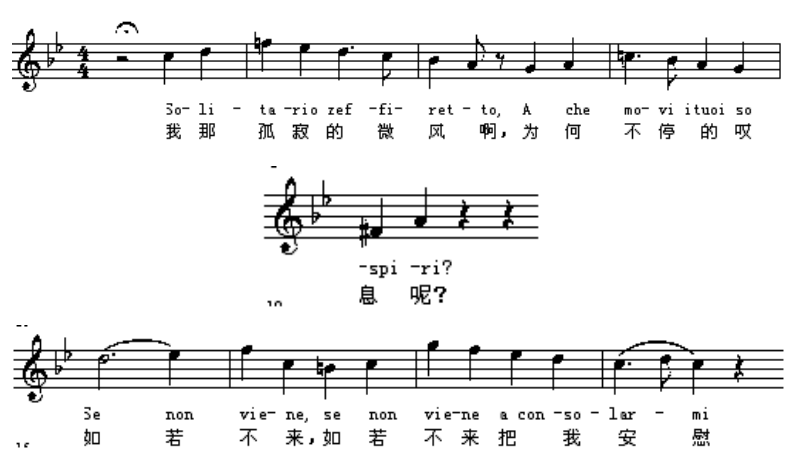

Fig. 4. Extracted from L'abbandono.

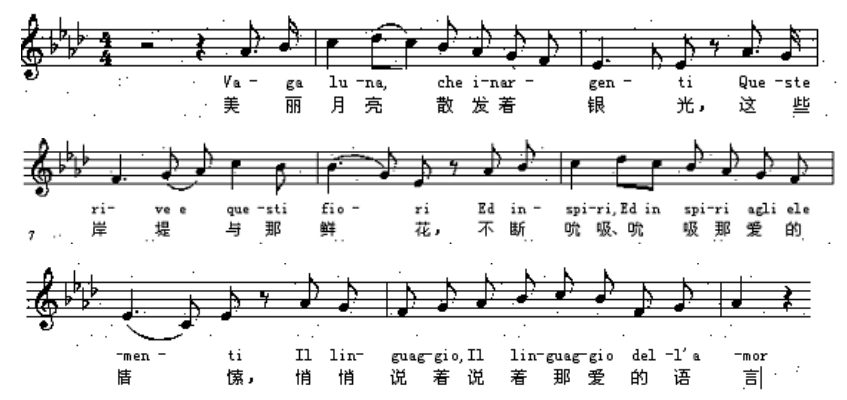

Fig. 5. Extracted from Vaga luna, che inargenti.

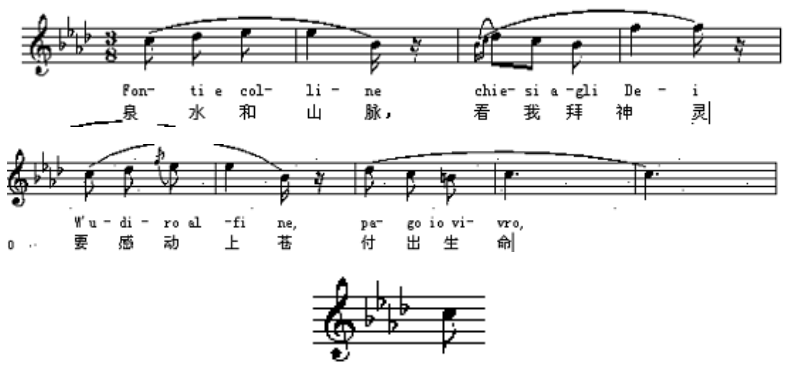

Fig. 6. Extracted from Malinconia, Ninfa gentile.

\section{B. The Scale-Styled Melody}

The scale-styled melody is used very frequently in Bellini's art songs, including the ascending-scale melody, descending-scale melody and the ascending-and-descending scale melody. They are all connected by secondo and tierce intervals continuously. The melody is smooth and soothing, while the melodic line is ups and downs and long-flowing. Such melody is quite characteristic as in "Fig. 7", "Fig. 8" and "Fig. 9".

1) Ascending-scale melody: The ascending-scale melody gives a positive and exciting psychological feeling. The works include Finestra che lucevi ed or non luci, Torna, vezzosa Fillide and Se il mio llolne saper voi bramate.

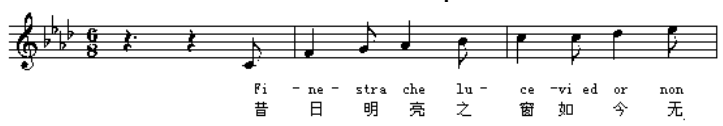

Fig. 7. Extracted from Finestra che lucevi ed or non luci.

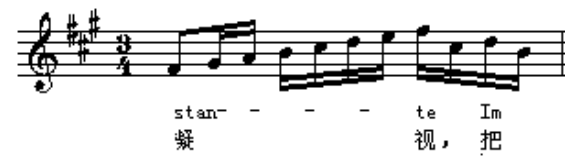

Fig. 8. Extracted from Torna, vezzosa Fillide.

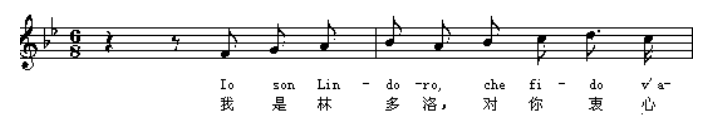

Fig. 9. Extracted from Se il mio llolne saper voi bramate.

2) Descending-scale melody: The descending-scale melody brings a psychological feeling of sigh, return, and a melancholy and sentimental psychological experience. The descending melody is most frequently used in Bellini's art songs, which also fully reflects that he was good at writing melancholy, mournful and gentle songs. The works include $\mathrm{O}$ crudel the il mio pianto, Bella Nice, che d'amore and Malinconia, Ninfa gentile as in "Fig. 10", "Fig. 11" and "Fig. $12 "$. 


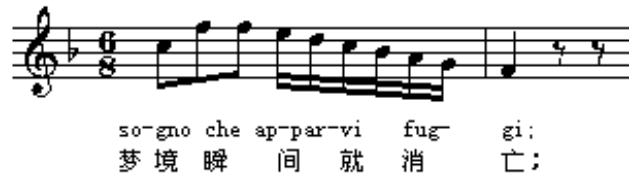

Fig. 10. Extracted from $\mathrm{O}$ crudel the il mio pianto.

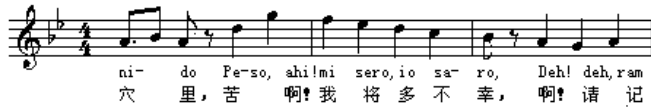

Fig. 11. Extracted from Bella Nice, che d'amore.

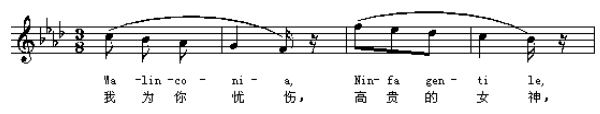

Fig. 12. Extracted from Malinconia, Ninfa gentile.

3) The ascending-and-descending scale melody: The ascending-and-descending scale melody is started from relatively low tone and then goes to relatively high tone, and then gradually descends to relatively low tone, forming a vaulted line. The secondo intervals make the vaulted line smooth, stable, balanced and symmetrical. Such works include L'allegro marinaro, Ma rendi pur contento, A palpitar d'affanno, Vaga luna che inargenti and Per piet't, bell idol mio as in "Fig. 13", "Fig. 14", "Fig. 15" and "Fig. $16 "$.

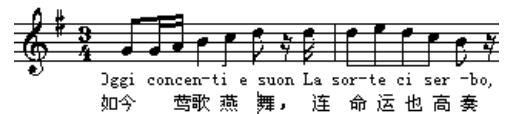

Fig. 13. Extracted from L'allegro marinaro.

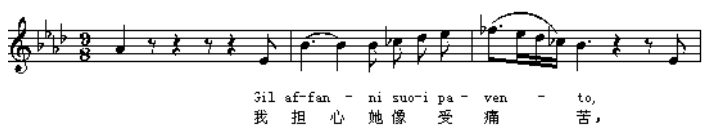

Fig. 14. Extracted from Ma rendi pur content.

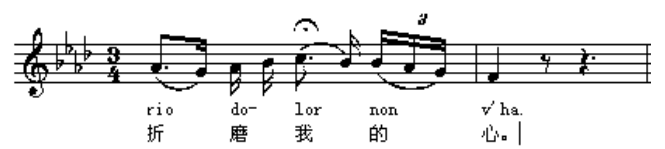

Fig. 15. Extracted from A palpitar d'affanno.

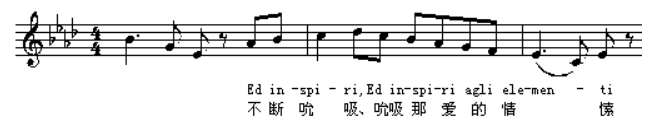

Fig. 16. Extracted from Vaga luna che inargenti.

\section{Anadiplosis Melody}

Bellini art songs often use the anadiplosis technique which makes the connection between phase to phase more natural and closer. The music is long-flowing, mild and pleasant, with delicate emotion. For instance, the works include Finestra che lucevi ed or non luci, La farfalletta, Per piet't, bell idol mio and Torna, vezzosa Fillide. "Fig. 17", "Fig. 18" and "Fig. 19"

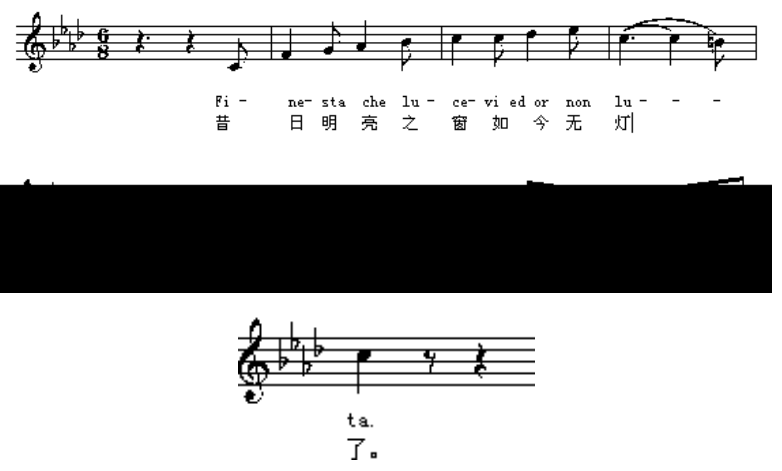

Fig. 17. Extracted from Finestra che lucevi ed or non luci.

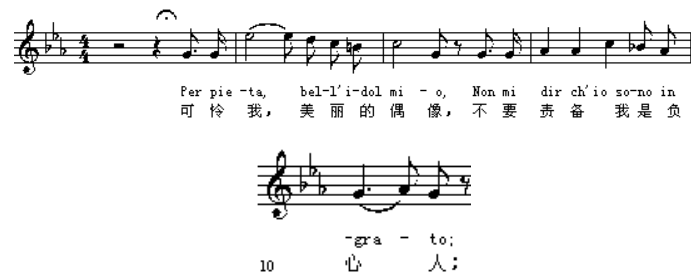

Fig. 18. Extracted from Per piet't, bell idol mio.

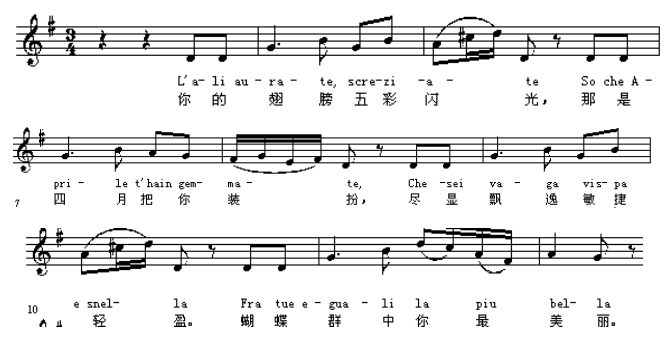

Fig. 19. Extracted from La farfalletta.

\section{Tremolo Melody}

The tremolo melody is often used in Bellini's art songs. The melody lingers around a main tone. Generally it is within secondo interval, and forms a sweet and ingenious melodic state. For example, the works include L'abbandono, Torna, vezzosa Fillide, Se il mio llolne saper voi bramate, Sogno d'infanzia and L'allegro marinaro.

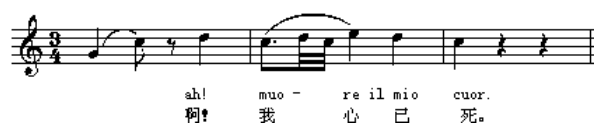

Fig. 20. Extracted from Sogno d'infanzia.

In the score, do and re can be viewed as main tones, and other notes revolve around within secondo interval and tierce interval. "Fig. 20" 


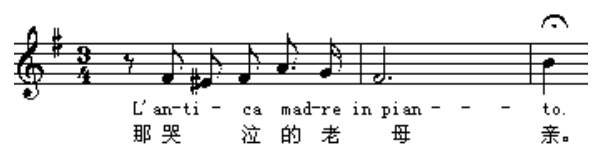

Fig. 21. Extracted from L'allegro marinaro.

In the score, fa can be viewed as the main tone. Other notes revolve around within secondo interval and tierce interval. "Fig. 21"

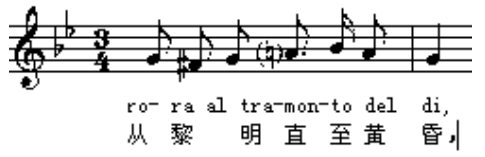

Fig. 22. Extracted from Se il mio llolne saper voi bramate.

In the score, so is the main tone, and other notes revolve around within secondo and tierce interval. "Fig. 22"

\section{E. Arpeggio Melody (Broken Chord Melody)}

In Bellini's art songs appear many arpeggio melodies which are carried out within tierce or fourth interval. It gives the melody a sense of leap and life. The music is gentle and lyric. For example, the works include Torna, vezzosa Fillide, Quando incise Stl quel marmot, A palpitar d'affanno, Vanne, $\mathrm{O}$ rosa fortunate and La farfalletta as in "Fig. 23", "Fig. 24", "Fig. 25" and "Fig. 26".

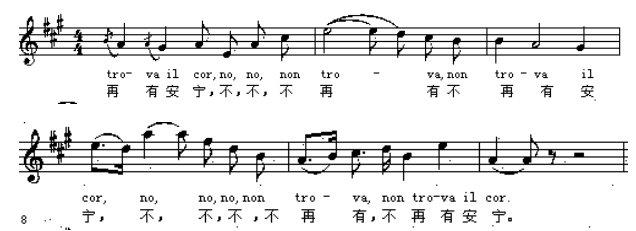

Fig. 23. Extracted from Torna, vezzosa Fillide.

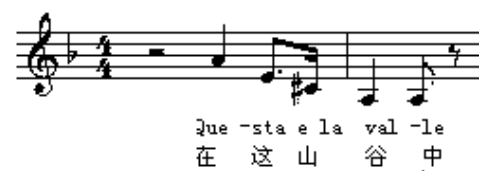

Fig. 24. Extracted from Quando incise Stl quel marmot.

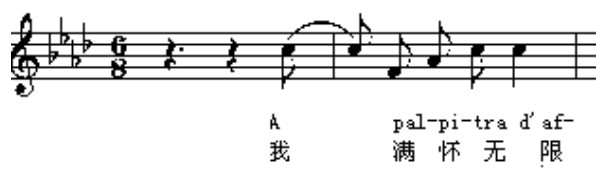

Fig. 25. Extracted from A palpitar d'affanno.

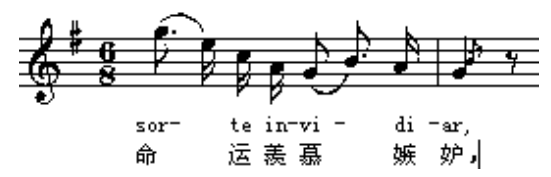

Fig. 26. Extracted from Vanne, O rosa fortunate.

\section{F. Fast Cabaletta Coloratura Melody}

In most of Bellini's art songs, the fast cabaletta coloratura melody often appears in the emotional climax at the end of phase. It goes stably within the secondo and tierce intervals, but the style of fast coloratura from the Baroque period is gorgeous and sweet. But for Bellini, the gorgeous coloratura is added for the need of music. It reveals real and natural and deep emotion of the author. It is not for showing off skills. For example, the works include Se il mio llolne saper voi bramate, Fervido desiderio and Quando incise St quel marmot as in "Fig. 27" and "Fig. 28".

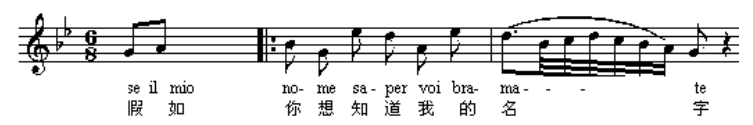

Fig. 27. Extracted from Se il mio llolne saper voi bramate.

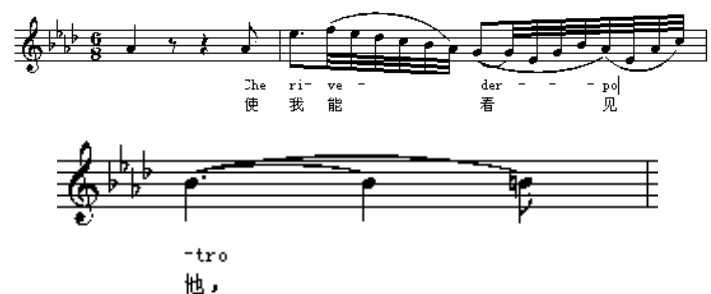

Fig. 28. Extracted from Fervido desiderio.

\section{G. The Great-leap Interval Melody at the End of Musical Phrase}

In Bellini's art songs, the great-leap interval melody often appears at the end of phase. It gives a sense of nerve and struggle and brings a dramatic sense of impact. For example, the works include Malinconia, Ninfa gentile, Almen se non poss' io, O crudel che il mio pianto non vedi, Torna, vezzosa Fillide and Sogno d'infanzia in "Fig. 29" and "Fig. 30".

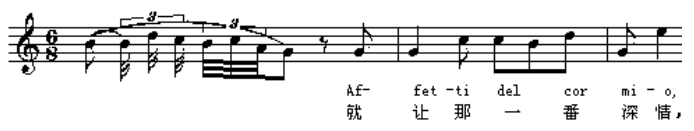

Fig. 29. Extracted from Almen se non poss’ io.

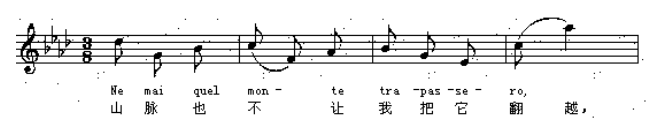

Fig. 30. Extracted from Malinconia, Ninfa gentile.

\section{H. Tercet Melody}

Bellini loves tercet very much. He often used tercet in his music. In Selection of Bellini's Art Songs, translated and edited by Jia Tao, there are 19 art songs. 13 of them have used tercet, including $3 / 4,3 / 8,6 / 8$ and $9 / 8$ (6/8 and 9/8 are respectively composed by two and three $3 / 8$; the paper has included them into tercet). Among 13 tercet music, 6/8 is most frequently used. Seven of them have used 6/8. The works in 3/4 include L'allegro marinaro, Sogno d'infanzia, La farfalletta and Dolente immagine di Fille mia. The work 
in 3/8 is Malinconia, Ninfa gentile. The songs in 6/8 include Finestra che lucevi ed or non luci, $\mathrm{O}$ crudel che il mio pianto non vedi, Se il mio llolne saper voi bramate, A palpitar d'affanno, Fervido desiderio, Vanne, O rosa fortunate and Almen se non poss' io. The song in $9 / 8$ includes Ma rendi pur contento.

The characteristics of the tercet melody are graceful, fluent, coherent and lyric. It is very rhythmic, consistent and lyrical. It is easy to express tender and sad emotions.

\section{CONCLUSION}

Through the specific analysis of the melody characteristics of Bellini's art songs, we can see that the melodies of his art songs have unique charm. They are very worthy of careful analysis and research. The melody of his art songs is smooth and soothing, with ups and downs. With long-flowing lyricism, it seems to be flexible, lively, sweet and broad. The gorgeous music also shows delicate and graceful tenderness and dramatic conflicts, which seems to be contradicted. But they are perfect and appropriate, deep and profound. These characteristics have established the title of melody master which has a great influence on the composition of Verdi, Chopin and Wagner in the later years. Of course, the analysis and study of the melody characteristics of Bellini's art songs is very helpful for us to learn, grasp and sing Bellini's art songs better, and it's also beneficial to improve vocal singing level, artistic accomplishment and teaching level of vocal music teachers.

\section{REFERENCES}

[1] Selection of Bellini's Art Songs, translated and edited by Jia Tao. Central Conservatory of Music Press, 2008.

[2] Collection of Bellini's Art Songs, translated by Zhou Tongfang. Full Music Score Publishing House, 1999.

[3] Introduction to the History of Western Music, edited by Shen Xuan and Gu Wenxian. Shanghai Music Publishing House, 1999.

[4] Critical Biography of Famous European Musicians, Guan Jinyi. Beiyue Literature and Art Publishing House, 2000.

[5] Foreign Music Dictionary, translated and edited by Wang Qizhang, Gu Lianli and Wu Peihua of Shanghai Institute of Music. Shanghai Music Publishing House, 1988.

[6] Music Bible, Lin Yicong. Huaxia Publishing House, 1999.

[7] http://www.shanghaiopera.com.cn/Gjtd_gjmj_show.asp? Info_id=212. 